\title{
Die tempel-metafoor in Efesiërs 2:11-22 as deel van identiteitsvorming van die gelowige in-groep
}

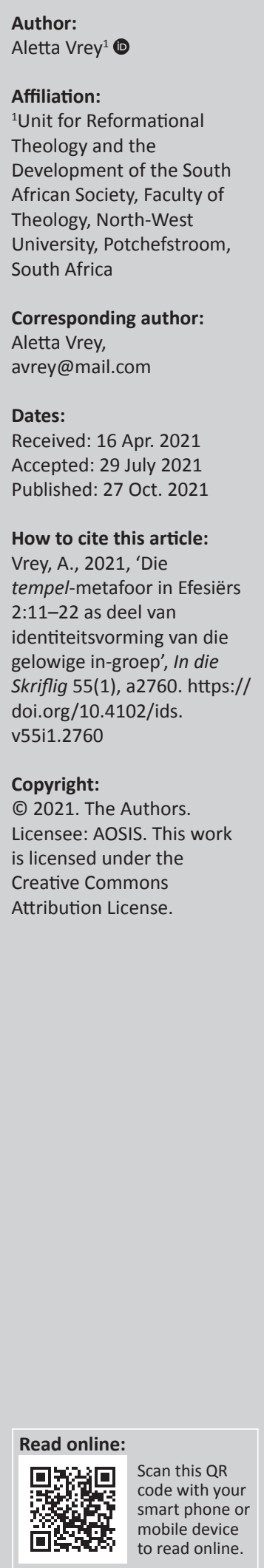

The temple metaphor in Ephesians 2:11-22 as part of identity formation of the believing in-group. One of the basic human needs is to belong, feel accepted and be part of a group. During the first century people from different backgrounds believed in Jesus, consequently unity among believers became a challenge. The inclusive heart of God, the atonement of Christ and the Holy Spirit unites believers from different backgrounds and groups. This article examines spiritual unity as part of the believers' identity as portrayed by the temple metaphor in Ephesians 2:11-22. Christians should acknowledge their differences, as the author of Ephesians clearly does, without causing division in the group. Identity formation is linked to group membership, therefore the identity of the early Christian group is examined, to determine the influence it still has on the present-day unity among believers. We divide our society into groups and tend to discriminate against those that are different from us. These phenomena were part of the social interaction of Christians in the first century. To better understand the social functioning of the ancient Mediterranean world, this article uses Social Identity Theory to identify and compare the groups in Ephesians. The Jews and Gentiles were the out-groups. In the context of the letter, Gentiles were Artemis-worshippers. The Christians formed the in-group. The identity of the out-groups, to which Christians previously belonged, should be considered to determine the identity of the in-group. The metaphor of the spiritual temple identifies believers as becoming part of the temple at the time of their conversion. Unlike the Jewish temple and the temple of Artemis, which were physical buildings with exclusive membership, the temple of the Holy Spirit is an inclusive unity of believers. The Jewish temple was part of the identity of the Jews, the Artemis temple gave identity to the city of Ephesus and the spiritual temple identifies the unity of the Christian in-group. The Christian-identity, whether in the first century or in contemporary society, is unifying and inclusive regardless of our differences. According to the author of Ephesians Christ-founded and Spirit-driven identity should determine Christian thinking and actions.

Contribution: The temple of Artemis and the Jewish temple were places of religious, political, economic and social status and power. The temple of Ephesians 2, however, becomes a spiritual force to which every believer has access apart from political, economic, social, ethnic and gender status. Christian identity and unity are rooted in the redemptive work of Christ.

Keywords: Ephesians; temple metaphor; Artemis temple; identity formation; social identity theory; Christian unity; in-groups; Jewish Gentiles.

\section{Inleiding}

Hierdie artikel doen 'n ontleding van die groepsidentiteite in die brief aan die Efesiërs om die invloed van die metafoor van die tempel in Efesiërs 2:11-22 op die eenheid en identiteit van die Christelike in-groepe te bepaal.

Die perspektiewe op Skrifgesag het oor die afgelope paar dekades verander en Cilliers (2003) stel dit soos volg:

Die Bybel word vandag beskou as God se woord, maar God se woord in en deur menslike taal - geskryf deur mense wat onlosmaaklik verbind was aan 'n bepaalde sosio-kulturele konteks. (bl. 23)

Volgens Cilliers moet die Bybel op verantwoordelike wyse gelees word met behulp van die historiese en linguistiese wetenskappe om die sosiale agtergrond van die Bybel te bepaal. Die etos, waardes en gebruike agter die teks moet binne die konteks van die oorspronklike gehoor in

Note: Die artikel is deels gegrond op die outeur se proefskrif: Vrey, A., 2016, "n Gender-kritiese ontleding van die groepsidentiteite in die brief aan die Efesiërs', PhD-proefskrif, Departement Godsdienskunde, Universiteit van Johannesburg, viewed 19 Maart 2021, from https://ujcontent.uj.ac.za/vital/access/BibliographyStatistics/Vrey,\%20Aletta 
ag geneem word. In 'n poging om die antieke Mediterreense wêreld se sosiale funksionering beter te verstaan, word daar in hierdie artikel gebruik gemaak van die Sosiale Identiteitsteorie (SIT) om die groepe wat in Efesiërs voorkom te identifiseer en met mekaar te vergelyk.

Een van die groot verskille tussen die hedendaagse samelewing en die samelewing van die antieke Mediterreense wêreld, is individualisme. Vandag speel die individu die sleutelrol in die vasstelling van identiteit, en Hanson en Oakman (1998) sê:

Individualism, self-sufficiency, self-esteem, personal identity, self-determination and autonomy are all highly valued. (p. 7)

Die klem op die individu sou vreemd wees in die antieke samelewing, want in daardie wêreld is identiteit bepaal deur die familie, beskermheer asook sosiale, godsdienstige en politieke groepe. Die behoeftes van die groep en lojaliteit aan die groep waaraan 'n persoon behoort het, was die waardes wat mense aan mekaar verbind het. Die samelewing het bestaan uit verskillende groepe met individue, wat die belange van hulle groepe verteenwoordig het. Godsdiens in die antieke Mediterreense samelewing was nie tot 'n sekere sfeer van die lewe beperk nie, maar was deel van die daaglikse lewe op politieke, ekonomiese en huishoudelike gebiede. Volgens Duling (2010:75) het die Romeine, net soos die Jode, geglo dat hulle die uitverkore mense van god was: 'Romans and Judeans considered themselves to be God's chosen people'. 'n Duidelike ooreenkoms tussen die gelowige ingroep en beide die Joodse en heidense uit-groepe, is dat hulle almal geglo het dat hulle uitverkies was en God se mense was. Volgens die SIT word stereotipering gebruik om deur middel van kategorisering die verskille tussen groepe te oordryf en in die proses word die ooreenkomste geïgnoreer. Deur die prosesse van sosiale kategorisering, identifisering en vergelyking sou al drie hierdie groepe, naamlik die heidense uit-groep, die Joodse uit-groep en die gelowige in-groep, glo dat hulle die spesiale, uitverkore groep was en dat al die ander juis dit was - die 'ander'.

Persone se optrede, sosiale status, waarde en identiteit is bepaal deur die groep waaraan hulle behoort het. Enige optrede wat afbreuk kon doen aan die status en eer van die groep, was ontoelaatbaar. Die kultuur van die tyd het veroorsaak dat mense met baie formele optrede hulle beste voetjie voorgesit het in ' $n$ poging om hulle groep se status te bevorder. Die individu se optrede, eer en waardes is dus vanselfsprekend ook aan sy groep toegeskryf (Malina 2001:58). Die groep waaraan ' $n$ individu behoort het, word voortaan as sy of haar in-groep beskryf.

Godsdiensbeoefening word meestal in die Westerse wêreld as ' $n$ persoonlike saak beskou. Dit was egter nie die geval in die antieke samelewings nie. Saldarini (1989:5) maak dit duidelik wanneer hy sê: 'In traditional society, religion was embedded in the political and social fabric of the community. Religion was integral to everything else and inseparable from it'. ' $\mathrm{n}$ Persoon is gebore in ' $\mathrm{n}$ familie wat alreeds gevestigde godsdienstige gebruike en tradisies gehad het en het eenvoudig die godsdiens, politiek, sosiale klas, en dus die identiteit van die familie aangeneem. Indien ' $n$ persoon radikale ander oortuigings as sy of haar familie en in-groep gehad het, sou dit dikwels tot verwerping lei. Joodse Judaïste is 'n goeie voorbeeld hiervan - 'n Jood is deel van die Joodse samelewing wat die kultuur, optrede, godsdiensgebruike en identiteit van sy Joodse in-groep insluit.

Godsdienstige leiers het politieke en sosiale magte in 'n samelewing geword wat die waardes, ideologieë en oortuigings van hulle volgelinge bepaal het. Soos Hanson en Oakman (1998:16) dit beskryf: 'Political religion, evident in the Jerusalem temple, enforced loyalty to the deity and the payment of taxes through divine law or group pressure'. Daar is nie veel ruimte gelaat vir innerlike oortuiging as motivering vir godsdienstige optrede nie. Die godsdienstige en politieke sisteme was inmekaar verweef en die leiers het die denkwyse van die volgelinge bepaal, deur hulle interpretasie van tekste, die verspreiding van kennis en die totale wêrelduitkyk te beïnvloed (Saldarini 1989:6-7). In die geval van Judaïsme, val hierdie verantwoordelikheid op die skouers van die Fariseërs, Sadduseërs en Skrifgeleerdes wat hulself gesien het as die egte verteenwoordigers van die ou Israel. Hulle sienswyses het die denkrigting van die volk bepaal en 'n invloed gehad op die skrywers en interpreteerders van die Bybelse tekste.

Die eerste eeuse gelowiges het ' $n$ nuwe in-groep gevorm; hulle was volgelinge van Jesus en was volgens die skrywer van Efesiërs ${ }^{1}$ nie meer deel van hulle vorige groepe nie. Hierdie nuwe gelowige in-groep se identiteit was nog besig om gevorm te word en die skrywers van die Nuwe Testament het die leiers geword wat die identiteit van Jesus-volgelinge vasgelê het. Die inklusiewe identiteit van die nuwe in-groep gelowiges word versterk deur gebruik te maak van die metafoor van die tempel in Efesiërs 2:11-22. Die boodskap van die metafoor vir die eerste eeuse gelowiges is steeds relevant in ons hedendaagse kultuur, aangesien eenheid ten spyte van verskille in die Christengemeenskap steeds ' $n$ uitdaging is.

Die doel van hierdie artikel is om te bewys dat die gelowige in-groep nie net verenig is deur hulle gemeenskaplike oortuigings en gebruike nie, maar deur die feit dat God hulle verenig. Gelowiges se verhouding met God, asook God se verhouding met ons, bring eenheid en identiteit in die groep. Die metafoor van die tempel dra by en bou op die inklusiewe identiteit van die gelowige in-groep. Die horisontale verhoudings met mekaar moet getuig van die eenheid wat daar in hierdie groep is as gevolg van hulle vertikale verhouding met God.

Christene kry 'n nuwe identiteit, nie op grond van hulle status as Jood of heiden, slaaf of vryman, man of vrou nie, maar as gevolg van hulle verhouding met Christus.

1.Aangesien daar nie konsensus is oor wie Efesiërs geskryf het nie sal daar in hierdie artikel verwys word na die skrywer van Efesiërs. 


\section{Sosiale Identiteitsteorie}

Sosiale Identiteitsteorie (SIT) ${ }^{2}$ word in hierdie artikel gebruik om ondersoek in te stel na die groepe in Efesieërs.

Die antieke Mediterreense kultuur was 'n kollektiewe samelewing wat in groepsverband gefunksioneer het.

Lidmaatskap van 'n groep het in hierdie kultuur ' $\mathrm{n}$ individu se optrede, status en identiteit bepaal; daarom is die samelewing deur middel van kategorisering gestruktureer en georganiseer in verskeie in-groepe en uit-groepe. In 'n poging om die identiteit van die vroeë gelowige in-groep vas te stel, is dit noodsaaklik om te bepaal wat was die identiteit van die uit-groepe waaraan hulle voorheen behoort het (Ef 2:1-3). Die skrywer van Efesiërs maak gebruik van stereotipes, vergelykings en metafore om die identiteit van die gelowige in-groep te bevestig en te versterk, deur dit met die heidense en Joodse uit-groepe te vergelyk.

Die in-groep in die brief aan die Efesiërs bestaan uit individue wat voorheen behoort het aan een van die twee uit-groepe, naamlik die heidene en die Jode, maar nou het hulle deel geword van die gelowiges. Van Driel (2020:48) voer aan dat gedurende tye van ingrypende verandering, dit belangrik is om die vraag te vra: Wie is ons? 'Without having a clear understanding of who we are, we will have no idea where to start as we engage our new context'. Efesiërs bespreek die eenheid van geloof wat gevorm moet word deur hierdie twee verskillende wêrelde, elk met hulle unieke kulture, tradisies en waardes, met mekaar te versoen en so 'n nuwe Christen-identiteit te vorm. Die proses om verskille vas te stel, speel 'n belangrike rol in sosiale verhoudings.

Die wêreld word volgens die SIT verdeel in 'hulle' en 'ons', en is gebaseer op die proses van sosiale kategorisering (Codol 1984:315). Die uit-groep heidene in en rondom Efese was waarskynlik deel van die Artemiskultus, en daar sal nou ondersoek ingestel word na hulle identiteit.

\section{Die rol van Artemis en haar tempel in die stad Efese}

Efese het baie wonderlike argitektoniese strukture gehad soos baddens, gimnasiums, stadions, teaters en sekerlik die bekendste, die tempel van Artemis (Trebilco 2004:15). In die teater van Efese het Demetrius teen Paulus en sy boodskap protes aangeteken volgens Handelinge 19:23-40. Die tempel van Artemis was die grootste gebou in die antieke wêreld, met 127 kolomme wat elk 20 meter hoog en twee meter in deursnee was. Dit was een van die sewe wonders van die wêreld (Hoehner 2002:83).

2.Die Sosiale Identiteitsteorie (SIT), (oorspronklik deur Henri Tajfel en John Turner in 1979 geformuleer), identifiseer en bespreek groepsidentiteit. Volgens die SIT het 1979 geformuleer), identifiseer en bespreek groepsidentiteit. Volgens die SIT he lidmaatskap van ' $\mathrm{n}$ groep ' $\mathrm{n}$ belangrike invloed op die manier waarop individu hulself en die wêreld sien en verstaan. Alle mense behoort aan een of ander groep en tree op as groepslede. Die basiese determinante vir groepsvorming is mense $\mathrm{s}$ sosiale verhoudings met ander, hulle gedeelde gesindhede en waardes, asook die sosiale norme en rolle wat hulle optrede bepaal. Hierdie determinante is van toepassing op die identiteit en status van die lede van die vroeë Christelike gemeenskap.
Die aanbidding van Artemis het die stad Efese se godsdienstige milieu oorheers. Daar word algemeen aanvaar dat die brief aan die Efesiërs gerig is aan Christene in Efese en die omliggende gebied, en daarom kan dit aanvaar word dat die Artemiskultus aan die lesers van die Efesiërs-brief bekend was. Die tempel van Artemis het ' $n$ belangrike rol in die stad se ekonomie gespeel. Daar is groot hoeveelhede geld in die tempel gestoor (Trebilco 2004:20-25). Die aanbidders van Artemis het die stad se voorspoed toegeskryf aan hulle godin wat Efese beskerm en versorg het. Volgens Brinks (2009:784) verskyn Artemis en haar tempel op muntstukke wat in die antieke Efese uitgegrawe is. Mans en vroue het die ampte in hierdie kultus beklee en het op gelyke wyse aan die feeste en rituele deelgeneem.

Die diens aan gode en godinne het verskillende funksies ingesluit, van die onderhoud van die tempel tot die beplanning en uitvoering van feeste, die priesterlike funksies, asook die uitvoering van sekere rituele. In kleiner dorpies was een of twee persone vir die uitvoering van hierdie take verantwoordelik, maar in die groter stede soos Efese, was daar ' $n$ gestruktureerde organisasie wat verantwoordelik was vir die kultus se funksies. Vroue het ook leiersrolle vertolk. Daar is bewyse dat daar Griekse priesteresse was in die kultusse van Demeter, Hera en Artemis. Hierdie priesteresse het reinigingseremonies uitgevoer en die tempelskatte en geskenke opgepas. As beloning vir hulle werk het hulle ' $n$ deel van die offers ontvang (Kraemer 1992:81). In die godsdiens-beoefening van die Grieke sowel as die Romeine was daar nie gender diskriminasie nie, maar eer en status wat die bepalende faktor was in die verkryging van kultusfunksies of -posisies.

Cotter (1994:358) voer aan dat die Romeinse kultuur die oorheersende kultuur in Efese was - selfs so vroeg as 100 jaar voordat Paulus na die stad gekom het. Efese was die derde grootste stad in die Grieks-Romeinse ryk, met slegs Rome en Athene wat groter was. Efese het geweldige ekonomiese groei beleef in die tydperk van die Pax Romana.

Alhoewel daar baie verskillende godsdienste beoefen is in die stad Efese, het dit bekend gestaan as die stad van Artemis. Haar primêre funksie was om Efese te beskerm en te onderhou. ${ }^{3}$ Treblico (2004:12-17) noem Artemis die koningin van die kosmos as gevolg van haar mag oor die bonatuurlike. Aangesien Efese die hoofsentrum was van die aanbidding van Artemis is dit nie vreemd dat Christus in Efesiërs beskryf word as die Hoof wat regeer oor al die magte van die kosmos nie. God se almag word beklemtoon in teenstelling met die heidense geloof dat Artemis die kosmos regeer het. Die heidense uit-groep het Artemis as hulle beskermvrou aanbid, terwyl die gelowige in-groep Jesus as hulle Verlosser en Heer aanbid het (Ef 1:20-23).

Die metafore van Efesiërs is volgens Perkins (1997) in reaksie teen heidense godsdienste:

3.Die verhouding tussen Artemis en Efese was nie vreemd in die antieke Mediterreense tyd nie, en volgens LiDonnici (1992:394) het dieselfde tipe verhouding bestaan tussen die godin Athena en die stad Athene. 
Since the emphasis on Christ's exaltation above the powers of the cosmos and the identification of believers with their exalted head forms the centre of Ephesians, this mystery might be read as a response to pagan religion. (p. 27)

Die skrywer van Efesiërs wil die in-groep se identiteit versterk deur hulle God as sterker uit te beeld as die uitgroep se godin. Volgens SIT is vergelyking deel van identiteitsvorming.

Na aanleiding van Handelinge 19:26-27 kan gesê word dat die gelowige in-groep in Efese vinnig gegroei het en dat hulle nie net uit Jode bestaan het nie, maar ook uit heidene wat Christus aangeneem het. Volgens Treblico (2004:164) het die teenwoordigheid van die Christene ' $n$ verlies aan inkomste vir Demétrius en ander ambagsmanne beteken. Hulle het hulle bestaan gemaak deur aandenkings te maak vir die Artemiskultus. In Efese het die Christendom teen die middel van die eerste eeu 'n godsdiens geword om mee rekening te hou. Die gelowige in-groep in Efese het uit voormalige Jode en heidene bestaan, heel moontlik Artemisaanbidders, wat nou in Jesus Christus geglo het.

Artemis is op die magshiërargie van gode en godinne as een van die mees senior lede beskou, en sy word as 'n politieke godin gesien wat betrokke was by die historiese en sosiale faktore wat die stad Efese geaffekteer het: 'The image of Artemis was an important focal point of Ephesian selfunderstanding; its fortunes, appearances, and modifications paralleled those of the polis itself' (LiDonnici 1992:395-396). Die identiteit van Efese is grootliks aan Artemis gekoppel. Sy is as die wettige vrou van die stad gesien en het dit beskerm en versorg, sê LiDonnici (1992):

... [T]rusty warden not only of the things in people's houses, but also of the financial resources on deposit at the Artemision; guardian of legitimate marriage; overseer of the birth of the next generation. These are categories of power, intimately connected with the stability and continuation of the family, city, the empire, and conceptually the universe. (p. 409)

Die primêre funksie van Artemis Ephsia was die beskerming en onderhouding van die stad Efese en die mense wat dit bewoon. ${ }^{4}$ Die Artemiskultus was ' $n$ integrale deel van alle aspekte van die Efesiërs se lewens.

Paulus se boodskap in Handelinge 19:26 was dat beelde wat met mense se hande gemaak word, nie gode is nie. Paulus se stelling het tot ' $n$ opstand in Efese gelei. Die inwoners van Efese sou nie toelaat dat daar met hulle godsdiens of ekonomiese welvaart ingemeng word nie. Brinks (2009) beweer dat die volgelinge van Artemis bekommerd was oor die mag van die Christenbeweging se God:

Luke's account of the riot in Ephesus cleverly and subtly compares Artemis with the God of the Christians and insinuates that even Artemis's worshipers believed that the goddess faced a serious threat from a more powerful deity. (p. 777)

4.Godsdienstige en politieke inskripsies verbind godinne met alle aspekte van die stedelike lewe. So word daar byvoorbeeld verwys na genesing van siektes, verkryging van krediet, asook die beskerming (LiDonnici 1992:394).
Vir die inwoners van Efese was 'n bedreiging van hulle godin so goed soos ' $n$ bedreiging teenoor hulself. Die boodskap wat Paulus versprei, kon ernstige ekonomiese gevolge vir die stad Efese inhou, aangesien mense juis na Artemis en haar tempel gestroom het en geld spandeer het aan aandenkings van die godin. Sy boodskap was dat die ware God in 'n heilige tempel woon, 'n woning in die Gees en nie 'n gebou van graniet en hout nie (Ef 2:21-22). Vir die Efesiërs het Artemis soveel politieke mag gehad dat hulle haar godsdienstig aanbid het, wat weer ekonomiese wins gebring het sodat hulle haar selfs meer vereer het. ${ }^{5}$ Die tempel was eerstens die plek van aanbidding vir die Artemiskultus, maar die tempel het ook ander funksies gehad. Artemis was die beskermvrou en versorger van Efese (Kampen 2003:218).

\section{Die tempel van die Jode}

In Efese het die Jesus-beweging onder die Jode begin. Volgens Treblico (2004:38) bestaan daar dokumentasie wat die Jode in Efese plaas vanaf 312 v.C. In hierdie dokumente word Jode vrygestel van militêre diens en die Jode in Efese kry toestemming om hulle tradisies en gebruike voort te sit hulle mag offers bring volgens hulle tradisies en hulle is toegelaat om die Sabbat te onderhou. Hierdie toegewings is dus gemaak en wetlik vasgelê al voor die koms van die Romeine. Die Joodse gemeenskap in Efese het gereeld byeengekom, hulle het sterk bande met die tempel in Jerusalem behou en is toegelaat om tempelbelasting na Jerusalem te stuur. Daar was 'n Joodse sinagoge in Efese waarin Paulus gepreek het volgens Handelinge 18:19.

Die pligte van die hoof van die sinagoge was om die geestelike rigting vir die Joodse gemeenskap aan te wys deur onderrig en prediking, en ook om ander lede van die gemeente te vra om te preek. Hy was ook verantwoordelik vir die finansiële onderhoud van die sinagoge en moes sorg vir bouwerk, restourasie en die instandhouding van die gebou. Die hoof van die sinagoge se finansiële posisie het ' $n$ rol gespeel in die aanstelling.

Baie van die metafore wat in die Nuwe Testament voorkom, is deur beelde van die $\mathrm{Ou}$ Testament geïnspireer.

In die Ou Testament het die volk die opdrag gekry terwyl hulle nog in die woestyn rondgeswerf het, om vir God ' $n$ woonplek te bou, in die vorm van die tabernakel. Tydens die hoogtepunt van die Joodse geskiedenis in die tyd van Dawid en Salomo, het God aan die volk opdrag gegee om vir Hom 'n tempel te bou van klip, goud en silwer. Die tempel was vir die Joodse volk 'n simbool van hulle godsdiens; God het in die tempel gewoon. Paulus sê in 1 Korintiërs 3:16: 'Weet julle nie dat julle 'n tempel van God is en die Gees van God in julle woon nie?' (OAV 1933). ${ }^{6}$ Hierdie woorde van Paulus is geskryf nog voordat die tempel in 70

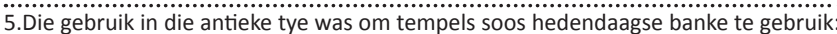
'As early as the fifth century B.C. the Artemis temple received deposits and lent money' (Johnson 1979:83).

6.Die Bybelverwysings is uit die Ou Afrikaanse Vertaling (OAV) en Nuwe Afrikaanse Vertaling (NAV) 
n.C. vernietig is. Vir die Jode was hierdie 'n totaal vreemde gedagte. Oor die eeue was God se woonplek in die tempel in Jerusalem, maar nou impliseer Paulus dat oral waar ons gaan, die tempel en God se teenwoordigheid met ons saamgaan. Die teenwoordigheid van God het dus van die tabernakel na die tempel in Jerusalem verskuif en in die eerste eeuse gelowige in-groep, het elke gelowige 'n tempel van die Heilige Gees geword. Webster (2012:215) se kommentaar op 1 Korintiërs 3:16 is: 'They are this temple by virtue of being indwelt by the Spirit'. In Efesiërs 2:22 (OAV 1933) staan: '.. in wie julle ook saam opgebou word tot ' $n$ woning van God in die Gees'. Die konteks en die tyd het verander en daarmee saam het die woonplek van God se Gees aangepas. Dit is van kritiese belang dat daar opgemerk word dat kulturele en konteksgebonde veranderinge plaasvind in die beoefening van godsdiens. Een so ' $n$ radikale verandering wat uitgebeeld word deur die metafore in Efesiërs, is die eenwording van die gelowige Jode en gelowige heidene as gelowige in-groep, deur die werking van die Heilige Gees.

\section{Die inklusiewe karakter van die brief aan die Efesiërs}

Die oorspronklike lede van die nuwe gelowige in-groep was Jode. Volgens Handelinge 2:5-11 was daar Jode van oor die hele wêreld in Jerusalem bymekaar met die uitstorting van die Heilige Gees. Handelinge 10 vertel van die bekering van Kornelius die Romeinse offisier, asook die uitstorting van die Heilige Gees op nie-Jode wat ook nou deel geword het van die gelowige in-groep. Die evangelie was nie net vir die Jode bedoel nie. In Handelinge 2:46-3:1 (OAV 1933) lees ons dat Jesus se dissipels nie opgehou het om na die tempel toe te gaan nie: 'En Petrus en Johannes het saam na die tempel opgegaan op die uur van die gebed, die negende uur'.

Hulle het nie opgehou om Jode te wees en sekere Joodse wette en tradisies na te kom nie. Hulle het geglo dat Jesus Christus die Messias en die Seun van God was wat uit die dood opgestaan het, maar hulle was steeds Jode wat grootgeword het met Joodse tradisies en wette. Na verloop van jare, is die gelowige in-groep Christene genoem $(\mathrm{Hd}$ 11:26). Dit was nadat ' $\mathrm{n}$ toenemende aantal nie-Jode ook Jesus-volgelinge geword het. Die skeiding tussen Judaïsme en Christendom het oor jare plaasgevind.

Die Jode was 'n eksklusiewe groep mense wat deur hulle geloof in God en hulle verbond met Hom saamgevoeg is. Dit was ' $n$ etniese en godsdienstige groep met wette en tradisies wat oor eeue gestrek het. Die Joodse in-groep het die heidene verag, en hulle beskou as die 'ander' of die 'onbesnedenes' (Ef 2:11). Hulle het hulself as die eksklusiewe volk van God beskou, deel van die verbond en beloftes van God. Daar het 'n skeidsmuur bestaan tussen hierdie groep en enige ander groep, hetsy heidene of Christene (Ef 2:14). MacDonald (2004) is van mening dat die tempel 'n deel van die identiteit van die Jode was, maar Jesus het die skeidsmuur kom afbreek en die voorhangsel het geskeur (Mk 15:38; Lk 23:45):
The temple is part of the legacy and prestige of Israel, and possible reference to its destruction may have been an attempt to articulate new boundaries in relation to issues of Jewish nationhood. Christ becomes the one who has made both Jew and Gentile one and has broken down the dividing wall. (p. 434)

Hierdie groep het geglo dat slegs hulle en die heidene wat die Joodse geloof aangeneem het, deel van God se volk is, en dat hulle dus eksklusiewe reg tot God se beloftes het (Ef 3:6). Tog word dit duidelik in Efesiërs 2:11-19 gestel dat Christus oor die wet getriomfeer het en die groot verdeeldheid wat die wet veroorsaak het, volgens die Jode, in die mensdom oorbrug het. Gombis (2004) stel dit so:

By his death, Jesus Christ has united into one new humanity the two formerly divided peoples. Whereas the Gentile readers were formerly outsiders in reference to the people of God, they now have been made a vital part of that community. (p. 414)

Yorke (2007) is van mening dat die skeidsmuur ook kan verwys na die Pax Romana en dat ware vrede in Pax Christi gevind word:

The community in Christ is a deconstruction of Roman imperial power and constitutes a counter social, economic, and political order of life. The auctor ad Ephesios is providing politico-rhetorical reassurance to his marginalized listeners. (pp. 120-121)

Die tempel van Artemis in Efese was ' $n$ indrukwekkende gebou en is gesien as een van die wonders van die antieke wêreld. In die Joodse kultuur het die tempel in Jerusalem 'n baie belangrike funksie vervul en was sentraal in hulle godsdiens-beoefening. Neufeld en DeMaris (2010) stel dit soos volg:

The Temple gave monumental expression to a sacrificial system that allowed the Judeans to maintain right relations with God by eliminating any unholiness that arose in daily life.

That system was but one node in an elaborate network of beliefs and practices that organized the entire Judean worldview. (p. 28)

In Efesiërs 2:21-22 word die in-groep beskryf as 'n 'heilige tempel' en 'geestelike huis'. God woon nie meer soos die uitgroepe se gode in mensgemaakte tempels nie, maar in die gelowiges van die in-groep.

Die beskermheerstelsel asook dié van eer en skande is twee sosiale stelsels wat die kultuur van die antieke wêreld oorheers het. Politieke, sosiale, ekonomiese en godsdienstige sisteme het op die beskerming en mag van die beskermheer en die lojaliteit van die kliënte staatgemaak. In Efese was Artemis die beskermvrou van die stad en van haar tempel; vir die Jode was God die beskermheer van Jerusalem en hulle tempel; en vir die in-groep van die brief aan die Efesiërs, is die Heilige Gees die beskermheer van elke gelowige wat nou 'n tempel van die Heilige Gees se teenwoordigheid is.

Die brief aan die Efesiërs kommunikeer leerstellings, oortuigings en norme aan die vroeë gelowige in-groep.

Een van die doelwitte daarvan is dat die in-groep se identiteit sterk gevestig kon word. In die eerste hoofstuk van Efesiërs 
word die geheimenis alreeds geopenbaar as die feit dat God 'alle dinge wat in die hemele sowel as wat op die aarde is, onder een hoof in Christus verenig' (Ef 1:10). In hoofstuk twee brei die skrywer uit op die uitsonderlike eenheid wat daar tussen Jood en heiden bewerk is deur Christus (Ef 2:11-16). Die boodskap van hoofstuk twee is dat God lede vanuit beide uit-groepe in Christus verenig en hulle nou as ' $n$ 'heilige tempel en woning van God' (Ef 2:21-22) saamgevoeg het. Hierdie lede het met hulle vorige groepe gebreek en opgehou om lede daarvan te wees. Eenheid en versoening tussen ('voormalige') Jode en ('voormalige') heidene het gekom - dit is die verborgenheid wat aan die skrywer geopenbaar is en wat hy aan die in-groep oordra.

Die primêre metafore in Efesiërs handel oor die in-groep wat uitgebeeld word as die liggaam, die tempel, die huisgesin, die bruid en die weermag. Hierdie metafore is goed in die brief ontwikkeld en kom voor op spesifieke en sentrale plekke. Die metafore van die tempel, huisgesin asook die liggaam dra almal die ondertoon van eenheid in die identiteit van die in-groep. Die horisontale verhoudings met mekaar moet getuig van die eenheid wat daar in hierdie groep is as gevolg van hulle vertikale verhouding met God. Die gelowige in-groep word nie net verenig omdat hulle dieselfde oortuigings en gebruike deel nie, maar primêr oor hulle verhouding met God en God se verhouding met hulle.

\section{Die Tempel-metafoor in Efesiërs}

In Efesiërs 2:19-22 vind ons twee metafore wat op ' $n$ baie kreatiewe wyse deur die skrywer vermeng word om die Kerk van Christus voor te stel as 'n huishouding en as 'n tempel. Grindheim (2003:543) meen dat die nuwe tempel die gelowiges uit die heidene insluit, en dat die basis van die metafoor van die tempel gevind kan word in die feit dat Christus die wet van Moses vervul het, en dat die Kerk die nuwe woonplek van God is. Foster (2007:87) ondersteun hierdie siening: 'Eph. 2:11-22 celebrates the new situation that the Gentiles enjoys as full members of the people of God'. Christene kry 'n nuwe identiteit, nie op grond van hulle status as Jood of heiden nie, maar as gevolg van hulle verhouding met Christus. In hierdie gedeelte (Ef 2:11-22) word daar spesifiek gepraat van 'julle' wat verwys na die heidene en 'ons' wat verwys na Israel, of die Jode.

Efesiërs 2:14 (NAV 1983) bevestig die inklusiewe eenheid in Christus:

Christus is ons vrede, Hy wat dié twee, Jode en nie-Jode, een gemaak het. Deur sy liggaam te gee, het Hy die vyandskap afgebreek wat vroeër soos ' $n$ muur skeiding gemaak het.

Die muur in die tempel wat skeiding gemaak het tussen Jood en heiden, is afgebreek (Duling 2003:276). Perkins (1997) is van mening dat die muur wat skeiding maak tussen Jood en heiden na die wet verwys, maar dat die wet nou vervul is in Christus en die skeidsmuur afgebreek is. Perkins (1997:72) stel dit soos volg: 'Destroying the "dividing wall" could only mean destroying the separation created by divergent legal rulings'. Voormalige lede van die twee groepe word nou as 'n eenheid saamgevoeg deur die verlossingswerk van Christus. Die Joodse tempel was nie toeganklik vir die heidene nie, maar as gevolg van Christus se versoeningswerk, is die muur afgebreek en daar word nie meer skeiding gemaak tussen Jood en heiden nie. Die muur is simbolies van dinge wat skeiding bring, naamlik die wet en die vyandskap wat daar tussen Jood en heiden was. Christus se versoeningswerk het egter bepaalde mense met God en ook met mekaar versoen (Thurston 1995:109). Keener (2003:212) verduidelik dit soos volg: 'For the Jewish and Gentile Christians of western Asia Minor, no greater symbol of the barrier between Jew and Gentile could exist than the dividing barrier in the Temple'. Daar was volgens Keener (2003:211) waarskuwings in die tempel in Jerusalem aangebring wat heidene verbied het in sekere gedeeltes van die tempel; oortreding van die reëling was met die dood strafbaar. Macpherson (1972) bevestig die inklusiewe karakter van die tempel-metafoor deur te sê:

If the death of Jesus is really about the breaking down of barriers between people, how can we account for the existence of Christians who accept racism or support an economic system which separates people along lines of class or colour? (p. 192)

Hoe kan enige diskriminasie dan aanvaarbaar wees in die Christengemeenskap? Nie net heidene is toegang geweier in sekere dele van die tempel nie; vroue is ook verbied. Soos reeds aangetoon, het heidene in Efese, hoofsaaklik Artemisaanbidders, nie vir sover dit godsdiens aangaan, onderskei ten opsigte van geslag nie, terwyl die Jode wél hierdie gender onderskeid in hulle godsdiensbeoefening getref het. Daar kan tereg gevra word: Hoe kan die versoeningswerk van Christus die gelyke vereniging van heidene in die gemeenskap van God impliseer, maar nie vir vroue nie? Ons kan tog nie glo dat die versoeningswerk van Christus beperkings het of voorwaardelik is op grond van gender nie. Die kruis van Jesus het absolute inklusiewe versoening en eenheid bewerk vir hulle wat 'in Christus is'.

Hierdie tempel waarvan Efesiërs praat, is nie deur mense gebou nie, maar word beskryf as die geestelike woning van God. Die skrywer brei uit op die metafoor van die gebou, en sê dat die fondament van die gebou uit die apostels en profete bestaan. ${ }^{7}$ Dit wil dus voorkom asof die fondament alreeds gelê is. Page (2005:41) skryf dat die apostels en profete die verbinding tussen Jesus en die Kerk was: 'They were the recipients of divine revelation and they provided the church with authoritative teaching to guide its faith and practice'. Die apostels en profete word in Efesiërs 3:5 en 4:11 ook genoem as die fondament waarop die Kerk gebou word. In 1 Korintiërs 3:917 word dieselfde metafoor gebruik, wanneer Paulus homself as argitek voorstel wat die fondament lê waarop ander soos Apollos bou, maar in hierdie geval is Christus die fondament.

7.In die Nuwe Testament word die apostels beskou as diegene wat saam met Jesus bedien het op aarde as die eerstehandse oog- en oorgetuies. Hulle was sy oorspronklike dissipels asook diegene met die gawe van apostelskap soos Paulus. Profete verwys heel moontlik na die Ou-Testamentiese profete wat die koms van Profete verwys heel moontlik na die Ou-Testamentiese profete wat die koms van Jesus voorspel het, asook na die Nuwe-Testamentiese persone met die gawe van profesie. Alhoewel Hoehner (2002:401) daarvan oortuig is dat dit slegs na NuweTestamentiese profete verwys, aangesien Efesiërs se boodskap van die eenheid tussen Jood en heiden asook die eenheid van die liggaam van Christus, nie ' $n$ Ou Testamentiese idee is nie, verduidelik hy dat die Nuwe-Testamentiese apostels baie soos die Ou-Testamentiese profete opgetree het: albei het openbarings van Go ontvang en dit met die mense gedeel en albei het met goddelike gesag opgetree. 
Die gelowige in-groep aan wie die brief gerig is, word gesien as die stene wat gebou word op die fondament van die apostels en profete. Die gevolgtrekking wat uit Efesiërs 2:2021 gemaak word, is dat die gelowiges ten tyde van hulle bekering stene word wat deel vorm van die gebou en soos met die metafoor van die liggaam, is daar interaktiewe afhanklikheid tussen Christus en die gelowiges, asook tussen die verskillende gelowiges. Christus vorm die hoeksteen en die gelowiges die stene, terwyl die apostels en profete die fondament gelê het.

Die woord wat vir gebou in Efesiërs 2:21 gebruik word, verwys volgens Hoehner (2002) na die proses van bou. Die tempel is nog besig om gebou te word; die metafoor verwys na 'n lewende en groeiende organisme, die Kerk. Die stene van die gebou word saamgevoeg om 'n tempel vir die Here te bou: 'As recipients of God's grace, they grow by being carefully fitted together rather than growing apart individually from one another' (Hoehner 2002:409). God is die Bouer wat moeite doen om die regte stene bymekaar te sit sodat daar eenheid en groei in die gebou, die Kerk, kan wees.

In Efesiërs 2:20 word Jesus as die hoeksteen van die gebou voorgestel en die gelowiges is die verskillende stene wat die nuwe gebou oprig. Dit is noodsaaklik om daarop te let dat vers 21 sê: 'in Christus sluit die hele gebou saam', hierdie gedeelte verwys vervolgens na Jesus as die sluitsteen; indien die sluitsteen verwyder word, val alles inmekaar. Die sluitsteen verskil van die hoeksteen, aangesien dit in die middel van die boë van die gebou is en twee dele saamvoeg. Die beeld van die steen kom voor in 1 Petrus 2:5, Psalm 118:22 en Jesaja 28:16. Die Ou-Testamentiese verwysings na die verwerping van die kosbare steen word in Efesiërs gebruik om te verwys na Jesus en sy verwerping as Messias. Christus is die fokuspunt van hierdie metafoor - die steen wat die ander stene rig, asook die steen wat alles bymekaar hou. Die kinders van God is die nuwe tempel wat besig is om gebou te word. In verhouding met Christus het alles 'n bepaalde plek (Kreitzer 1997:92-96). In verband met die sluitsteen skryf Perkins (1997):

Its location at the top of an arch also fits Ephesians consistent references to the exaltation of Christ (4:16). The unity of the initially separate 'you' and 'us' gains the organic form of a building whose diverse materials must be properly fitted together and held in place by the capstone. (p. 76, 78)

Daar is twee stene: vers 20 verwys na die hoeksteen, wat 'n rigtende funksie het, en vers 21 wat verwys na die sluitsteen, wat 'n samebindende funksie het. Die gelowige se posisie word deur Christus se posisie bevestig, naamlik Christus is die hoeksteen wat ons rig en die sluitsteen wat die gelowiges almal saambind om die tempel te bou (vgl. Ef 2:20-22). Die implikasie is dat ons nie sonder Christus of sonder ander gelowiges kan bou aan die heilige tempel nie. Die tema van eenheid en inklusiwiteit kom sterk na vore in hierdie metafoor.

Die simboliek van die tempel is iets wat almal in die antieke wêreld geken het, aangesien dit die blyplek van die gode was. Die tempel van Artemis was 'n landmerk in Efese en die woonplek van dié godin. Die God van die gelowige in-groep woon ook in 'n tempel, maar sy tempel verskil van die Joodse tempel en van Artemis se tempel, die twee uit-groepe wat in Efesiërs aangespreek word. In Handelinge 17:24 (OAV 1933) staan:

God, wat die wêreld met alles wat daarin is gemaak het, Hy is die Here van die hemel en die aarde, en Hy woon nie in tempels wat deur mense gemaak is nie.

Die metafoor verwys nie na ' $n$ fisiese gebou nie, maar na die blyplek van God. Grindheim (2003:538) ${ }^{8}$ stel dit so: 'Under the old covenant God dwelt among his people. Now, the community of believers is his dwelling'. Die Ou-Testamentiese tempel was die gebou waarin God gewoon het en teenwoordig was, maar Efesiërs se tempel is ' $n$ geestelike beeld wat gelowiges voorstel wat 'n woonplek vir God op aarde bewerkstellig.

Die veronderstelling is dat God teenwoordig was in die tempel, en deur die gelowiges nou as tempel uit te beeld, stel die skrywer die feit van die saak dat die gelowiges die teenwoordigheid van God in die wêreld indra.

Lemmer (1998) verbind die metafoor van die liggaam en die hoof (Ef 2:16; 3:6; 4:4; 4:12-16) met dié van die tempel en die hoeksteen:

It may not be too farfetched to assume that the metaphor is somehow related to the Headship idea. Thus this building, made up of its constituents, reaches into the heavenlies, where it is joined together in the capstone. (p. 488)

Die sluitsteen en die hoof is albei simbolies van Christus se leierskap, terwyl die liggaam en die gebou albei simbolies is van die gelowige in-groep.

Gombis (2004:408) verduidelik die wyse waarop oorloë in die antieke tyd gevoer is en vergelyk dit met die geestelike oorlog wat in Efesiërs uitgebeeld word. In Efesiërs 1 en 2 word die volgende goddelike oorlogspatroon gevolg:

The pattern in this passage is as follows: Lordship (1:20-23), conflict-victory (2:1-16), victory shout (2:17), celebration (2:18) and house-building (2:20-22). (p. 408)

God het alle magte onderwerp aan Christus, waarna Christus hierdie magte verslaan het. Volgens Gombis (2004:416) spreek die toegang tot die Vader waarvan Efesiërs 2:18 getuig, van die aanbidding wat die Joodse gelowiges en die heidense gelowiges saam in die tempel beoefen. Die gelowiges vorm die geestelike huis waarin God kan woon om naby aan die kinders van sy huisgesin te wees: 'This new creation that God has inaugurated, this new humanity, is also the place where God now dwells by his Spirit. The church is God's new temple' (Gombis 2004:417).

Al die gelowiges, voormalige heidene en voormalige Jode, word saam as lewende stene van die nuwe geestelike tempel

8.Daar is gedeeltes wat beklemtoon dat Christus deur Sy Gees in elke gelowige woon (Ef 1:19; 3:16-17; 4:4-5; 5:18) en daar is gedeeltes wat beklemtoon dat Christus in die gemeente as die korporatiewe eenheid woon (Ef 1:23; 2:21-22). 
opgebou. In die proses van identiteitsvorming vind sosiale gelykstelling plaas. God woon nie meer in 'n mensgemaakte tempel soos Artemis en die ander heidense gode nie, maar elke gelowige is nou deel van die woonplek of tempel van die Heilige Gees. Die feit dat die skrywer die metafoor van die tempel van toepassing maak op die gelowiges, kondig verandering en vernuwing aan, die nuwe gelowige in-groep is nie langer eksklusief vir Jode nie, en verteenwoordig nie meer eksklusief hulle tradisies en gebruike soos die aanbidding in die tempel in Jerusalem nie. Jesus se verlossingswerk maak die gelowige in-groep inklusief, sodat elke mens wat in Jesus glo, 'n lewende steen in sy heilige tempel word.

Jesus het die gelowiges gered van 'n waardelose bestaan, om saam opgebou te word as sy geestelike tempel (Ef $1: 13 ; 2: 18-22)$. Sy genade het aan hulle 'n posisie in God se plan gegee. Webster (2012:203) beskryf God se genade as die oorsprong van ekklesiologie. Dit is gepas dat die brief eindig met 'n oproep aan die gelowiges om betrokke te raak in 'n geestelike geveg (Ef 6:11-12). In verband met hierdie geveg, skryf Shkul (2009):

It is highly significant that the letter closing calls the community for a spiritual - not political or social - battle as Ephesians imagines conflict in spiritual terms, not as political or social oppression. Alternatively, it could imagine spiritual oppression behind any socio-political conflict. (p. 211)

Alhoewel die tempel van Artemis asook die Joodse tempel in Jerusalem 'n plek van godsdienstige, politieke, ekonomiese en sosiale status en mag was, word die tempel van Efesiërs 2 'n geestelike mag, waartoe elke gelowige in die in-groep toegang het, afgesien van hulle politieke, ekonomiese, sosiale, etniese en gender status.

Interpreteerders interpreteer ' $n$ teks volgens hulle eie verwysingsraamwerk. Soskice (1985) skryf:

... [W] interpret texts and they interpret us, they interpret our experiences; and it is not simply that we interpret texts, for we also interpret the experiences which they more or less obscurely chronicle. (p. 159)

Dit is baie moeilik, indien hoegenaamd moontlik, om totaal objektief te staan wanneer ' $n$ teks geïnterpreteer word. Die tradisionele, patriargale en androsentriese kommentare interpreteer die metafore in Efesiërs vanuit die tradisie van oorheersing en dominansie, terwyl die bevrydingsteologie en feministiese hermeneutiek dieselfde teks vanuit 'n posisie van onderdrukking interpreteer. In verband met die Bybel skryf Soskice (1985:160): 'Its sacred texts are chronicles of experience, armouries of metaphor, and purveyors of an interpretive tradition'. Die skrywer en die interpreteerder van enige teks bly mense met ervarings en tradisies en 'n sosiale en kulturele agtergrond. My eie agtergrond as ' $n$ vrou wat deel is van die metaforiese geestelike tempel, interpreteer hierdie teks as gelykstellend en inklusief.

Die doel van die skrywer van Efesiërs is om die gelowige ingroep in die eerste eeu se Christus-gefundeerde en
Geesgedrewe identiteit te bevestig en te versterk, om sodoende hulle denke en optrede te bepaal. Mouton (2002:114) beskryf dit as volg: 'It has become clear that Ephesians' perspective is in the first place christologically oriented, and aimed at the reorientation of the readers' identity awareness and ethos'. Die skrywer gebruik taal om die versterking en verfyning van die bestaande geloofsfondament in die gelowige ingroep te bevestig - dit sluit in die metafoor van die tempel.

\section{Konklusie}

Christus het gekom om bevryding, gelykheid en vryheid vir almal (Jood of heiden, slaaf of vryman, man of vrou) te bring. In verband met die lees van Efesiërs en die identiteit van die leser in Christus, skryf Mouton (2002:255): 'Subsequent readers of the New Testament may thus celebrate the creative tension of their ongoing dialogue with Ephesians as the remembrance of their identity and potential in Christ'. Ons almal wat in Christus glo, is deel van die tempel van die Heilige Gees. Ons identiteit en potensiaal lê in die verlossingswerk van Christus; 'n verlossing wat nie afhanklik is van status, etnisiteit, gender of enige ander beperkende faktor nie. In die woorde van Appiah (2018:183): 'Identity can be used to divide, but it can and has also been used to integrate'.

Die skrywer van Efesiërs se poging om die inklusiewe identiteit van die in-groep te versterk, is suksesvol rakende die sub-groep Joodse gelowiges en die sub-groep heidense gelowiges; die nuwe identiteit gaan gepaard met nuwe gedrag, gewoontes en standaarde. Die eenheid en gelykheid wat Jesus bewerk het aan die kruis, het die eenheid van Joodse en heidense gelowiges tot gevolg gehad. Die boodskap van Efesiërs se tempel-metafoor is dat eenheid deel is van die identiteit van die gelowige in-groep. Van Driel (2020) is van mening dat Christus in Efesiërs 'n eskatologiese werk doen:

Christ already makes visible to a watching world how the future will appear, as he brings together people from different walks of life and backgrounds and knits them into a new community. (p. 62)

Ongelukkig is die gelyke, inklusiewe identiteit nog nie ' $n$ realiteit vir alle sub-groepe in die gelowige in-groep nie. Die in-groep gelowiges het bestaan uit almal wat in Jesus Christus glo, en hulle het 'n figuurlike familia Dei [huishouding van God] gevorm.

Die skrywer van Efesiërs dui aan dat die in-groep uit verskillende sub-groepe bestaan wat soos volg geïdentifiseer word: die heidense gelowiges, die Joodse gelowiges, die manlike gelowiges, die vroulike gelowiges, die kinders, die ouers, die slawe en die eienaars (Ef 2:11-14; 5:22-23; 6:1-5). Fukuyama (2019:164) verduidelik dat daar in elke groep ook sub-groepe bestaan: 'Identity politics thus engenders its own dynamic, by which societies divide themselves into smaller and smaller groups by virtue of their particular "lived experience". Hierdie groepe binne in die in-groep kan onderskei word op grond van: 'skin color, gender, national origin, looks, ethnicity or sexual orientation' (Fukuyama 2019:164). Die inklusiewe identiteit van die gelowige in-groep het 
gedurende die eerste eeu soos vandag nog beteken dat daar sub-groepe in die in-groep bestaan. Die vraag ontstaan of inklusiwiteit ook volkome gelykheid vir die verskillende sub-groepe beteken? Ongelukkig is die antwoord op hierdie vraag, in my opinie, na 2000 jaar nog steeds: Nee!

Kok (2010) argumenteer dat die:

... [U] niversele goddelike narratief sentreer om die missio Dei, waarvolgens God, gemotiveer deur sy liefde vir 'n gebroke wêreld wat in geestelike doodsbestaan verkeer, sy Seun stuur om 'n herskepping teweeg te bring. (bl. 375)

Liefde is die motief en bedoeling van God se plan waarvolgens die herskepping teweeg gebring word. Die hart van die evangelie is om die buitestaanders tot geloof asook 'n nuwe identiteit en etiek te bring. Die missionêre inklusiewe identiteit van die in-groep gelowiges bring die boodskap van die evangelie oor sosiale, geografiese, kulturele, ekonomiese, etniese, gender en enige ander grense. Volgens Kok en Niemandt (2009) is die 'etos' van 'n gemeenskap hulle waardes, gebruike, manier van lewe en die besluite wat hulle neem:

As Christians, the basis or motivation for our being is built on the grounds of a particular understanding of God, of the world and of God's story for the world. Ethos is, in other words, the conduct of those who share a common identity. (p. 503)

Die vraag ontstaan wat was die etos van die gelowige in-groep, en het dit met die inklusiewe missie van Jesus se lewe en dood ooreengestem? Die skrywer van Efesiërs beantwoord hierdie vraag deur die inklusiewe metafoor van 'n geestelike tempel in Efesiërs 2:11-22.

\section{Erkenning \\ Mededingende belange}

Die outeur verklaar dat daar geen finansiële of persoonlike verbintenis is met enige party wat haar nadelig kon beïnvloed in die skryf van hierdie artikel nie.

\section{Outersbydrae}

A.V. was die enigste outeur betrokke by die skryf van die artikel.

\section{Etiese oorwegings}

Hierdie artikel het alle etiese standaarde vir navorsing gevolg.

\section{Befondsing}

Hierdie navorsing het geen spesifieke toekenning ontvang van enige befondsingsagentskap in die openbare, kommersiële of nie-winsgewende sektore nie.

\section{Data beskikbaarheid}

Die outeur bevestig dat die data wat die bevindings van hierdie studie ondersteun, beskikbaar is in die artikel.

\section{Vrywaring}

Die sienings en menings wat in hierdie artikel uitgedruk word, is dié van die outeur en weerspieël nie noodwendig die amptelike beleid of posisie van enige geaffilieerde verwantskap van die outeur nie.

\section{Literatuurverwysings}

Appiah, K.A., 2018, The lies that bind: Rethinking identity: Creed, country, colour, class, culture, Profile Books, London.

Brinks, C.L., 2009, 'Great is Artemis of the Ephesians: Acts 19:23-41 in light of goddess worship in Ephesus', Catholic Biblical Quarterly 71(4), 776-794.

Cilliers, J., 2003, 'Die verhouding tussen Skrifbeskouing en prediking', Nederduitse Gereformeerde Teologiese Tydskrif 44(1-2), 20-28.

Codol, J., 1984, 'Social differentiation and non-differentiation', in H. Tajfel (ed.), The social dimension, vol. 1, pp. 314-333, Cambridge University Press, Cambridge.

Cotter, W., 1994, 'Women's authority roles in Paul's churches: Countercultural or conventional', Novum Testamentum 36(4), 350-372. https://doi. org/10.1163/156853694X00238

Duling, D.C., 2003, The New Testament history, literature, and social context, Wadsworth/Thomson Learning, Belmont.

Duling, D.C., 2010, 'Ethnicity and Paul's letter to the Romans', in D. Neufeld, \& R.E. DeMaris (eds), Understanding the social world of the New Testament, pp. 68-89, Routledge, New York, NY.

Foster, R.L., 2007, 'A temple in the Lord filled to the fullness of God: Context and intertextuality (Eph.3:19)', Novum Testamentum 49(1), 85-96. https://doi. org/10.1163/004810007X163127

Fukuyama, F., 2019, Identity: Contemporary identity politics and the struggle for recognition, Profile Books, London.

Gombis, T.G., 2004, 'Ephesians 2 as a narrative of divine warfare', Journal for the Study of the New Testament 26(4), 403-418. https://doi.org/10.1177/0142064 X0402600402

Grindheim, S., 2003, 'What the OT prophets did not know: The mystery of the church in Eph 3:2-13', Biblical Studies on the Web 84, 531-553.

Hanson, K.C. \& Oakman, D.E., 1998, Palestine in the time of Jesus: Social structures and social conflicts, Fortress, Minneapolis, MN.

Hoehner, H.W., 2002, Ephesians: An exegetical commentary, Baker Academic, Grand Rapids, MI.

Johnson, S.E., 1979, 'The apostle Paul and the riot in Ephesus', Lexington Theological Quarterly 14(4), 79-88.

Kampen, J., 2003, 'The cult of Artemis and the essenes in Syro-Palestine', Dead Sea Discoveries 10(2), 205-220. https://doi.org/10.1163/156851703322235386

Keener, C.S., 2003, 'Some New Testament invitations to ethnic reconciliation', Evangelical Quarterly 75(3), 195-213. https://doi.org/10.1163/27725472-07503001

Kok, J., 2010, 'Die rol van die etiek in die prediking: Nuwe navorsing in NuweTestamentiese etiek en die implikasie daarvan vir die prediking', Verbum et Ecclesia 31(1), 375. https://doi.org/10.4102/ve.v31i1.375

Kok, J. \& Niemandt, C.J.P., 2009, '(Re)discovering a missional-incarnational ethos', HTS Teologiese Studies/Theological Studies 65(1), 502-508. https://doi.org/10.4102/ hts.v65i1.274

Kraemer, R.S., 1992, Her share of the blessings: Women's religions among Pagans, Jews and Christians in the Greco-Roman World, Oxford University Press, New York, NY.

Kreitzer, L.J., 1997, The Epistle to the Ephesians, Epworth Press, London.

Lemmer, R., 1998, 'Understanding "Body of Christ" in the Letter to the Ephesians', Neotestamentica 32(2), 459-496.

LiDonnici, L.R., 1992, 'The images of Artemis Ephesia and Greco-Roman worship: A reconsideration', The Harvard Theological Review 85(4), 389-415. https://doi. org/10.1017/S0017816000008208

MacDonald, M.Y., 2004, 'The politics of identity in Ephesians', Journal for the study of theNewTestament 26(4),419-444. https://doi.org/10.1177/0142064X0402600403

Macpherson, D., 1972, Paul 1, Sheed \& Ward, London.

Malina, B.J., 2001, The New Testament world insights from cultural anthropology, Westminister John Knox Press, Louisville, KY.

Mouton, E., 2002, Reading a New Testament document ethically, SBL, Atlanta, GA. (Academia Biblica 1).

Neufeld, D. \& DeMaris, R.E., 2010, Understanding the social world of the New Testament, Routledge, New York, NY.

Page, S.H.T., 2005, 'Whose ministry? A re-appraisal of Ephesians 4:12', Novum Testamentum 47, 26-46. https://doi.org/10.1163/1568536053602631

Perkins, P., 1997, Ephesians, Abingdon, Nasville, TN.

Saldarini, A.J., 1989, Pharisees, Scribes and sadducees in Palestinian Society, Clark International, Edinburgh

Shkul, M., 2009, Reading Ephesians: Exploring social entrepreneurship in the text, Clark International, New York, NY.

Soskice, J.M., 1985, Metaphor and religious language, Clarendon, Oxford. 
Tajfel, H. \& Turner, J.C., 1979, 'An integrative theory of intergroup conflict', in W.G. Austin \& S. Worchel (eds.), The social psychology of intergroup relations, pp. 33-47, Brooks/Coole, Monterey, CA.

Thurston, B., 1995, Reading Colossians, Ephesians and 2 Thessalonians: A literary and theological commentary, The Crossroad Publishing, New York, NY.

Trebilco, P., 2004, The early Christians in Ephesus from Paul to Ignatius, Mohr Siebeck, Tübingen.

Van Driel, E., 2020, 'Rethinking church in a Post-Christian age', in E.C. van Driel (ed.), What is Jesus doing? God's activity in the life and work of the church, pp. 47-70, IVP, Downers Grove, II.
Vrey, A., 2016, " $n$ Gender-kritiese ontleding van die groepsidentiteite in die brief aan die Efesiërs', PhD-proefskrif, Departement Godsdienskunde, Universiteit van Johannesburg, viewed 19 Maart 2021, from https://ujcontent.uj.ac.za/vital/ access/BibliographyStatistics/Vrey,\%20Aletta

Webster, J., 2012, “'In the Society of God": Some principles of Ecclesiology', in P. Ward (ed.), Perspectives on Ecclesiology in ethnography, pp 200-222, Eerdmans, Grand Rapids, MI.

Yorke, G., 2007, 'Hearing the politics of peace in Ephesians: A proposal from an African postcolonial perspective', Journal for the Study of New Testament 30(1), 113-127. https://doi.org/10.1177\%2F0142064X07081549 